\title{
ALEPPO - BEFORE AND AFTER
}

\author{
G. Fangi \\ Università Politecnica delle Marche, Ancona, Italy - Email: gabrielefangi@gmail.com
}

\section{Commission II}

KEY WORDS: Syrian Threatened Cultural Heritage, Spherical Photogrammetry

\begin{abstract}
:
In October 2018 I was in Aleppo, Syria, for my second time after the visit in 2010 before the war. It was an unique opportunity to perform 3D surveys of some noticeable buildings and monuments affected by the war. The paper shows some 3D results and comparisons for same monuments. The objects of the survey are some parts of the Citadel walls, the entrance tower of the Citadel, the southern tower, one mosque, the minaret of the Citadel mosque. These results prove undoubtedly that photogrammetry is an essential instrument for the 3D documentation and digital preservation of cultural heritage. The used technique is spherical photogrammetry, based on panoramic images and ad-hoc processing processes. The technique is very much suitable for heritage documentation and if will be transferred to the students of the local faculty of architecture.
\end{abstract}

\section{THE STORY OF MY SYRIAN SURVEYS}

\subsection{Introduction}

It happened to me to be in Aleppo, Syria, before the war in 2010 and once again in October 2018. That was the occasion to produce $3 \mathrm{D}$ surveys of some noticeable heritage buildings and monuments affected by the local war.

The used technique is spherical photogrammetry (Fangi, 2007; Fangi and Nardinocchi, 2013), fast in the acquisition phase, based on very simple photographic equipment (i.e. a camera, a tripod and a longimeter). Results of spherical photogrammetry applied to the Syrian monuments were presented in Fangi and Wahbeh (2013) - digital reconstruction of the minaret of the Great Mosque or Umayyade Mosque destroyed in 2012, Fangi (2015) and Fangi et al. (2016).

In October 2018 the Polytechnic University of the Marche organized an exhibition entitled "The Lost Syria, the Geomatics documents", with 28 surveys displayed in large panels and supported by videos. The students of the course of photogrammetry were responsible for carrying out the restitutions of the surveyed Siryan monuments (Di Stefano, 2016). A video of the 3D reconstruction was seen by Ms. Reme Sakr, Head of the Living Heritage Program of the Syrian Trust for Development a Syrian NGO, and she proposed me to come back to Syria and visit Damascus and Aleppo. The surveying mission took place from October 1st to October $15^{\text {th }}, 2018$. Some monuments had already been surveyed in 2010 , some others were surveyed ex-novo.

In the next sections some results of the achieved results and pre/after war comparison for same monuments (parts of the Citadel walls, the entrance tower of the Citadel, the southern tower, one madrasa, the minaret of the Citadel mosque) are presented.

The results prove undoubtedly that a photogrammetric survey is an essential instrument for the documentation and (digital) protection of monuments. What is shown here is the first stage of the work. The evaluation of the damages caused by the war to Syrian cultural heritage is a process that requires a long process of which the photogrammetric restitution is only a first step.
A) Monument where the comparison between "before" and "after", feasible as surveys of both periods are available:

- Minaret

- Medrasa AlHaways (interior and court)

Southern Tower and in general the walls of the citadel Interior facade of Khan Al Wasir caravanseray A very typical place inside the souq Entrance gate of the Ayubbids palace inside the Citadel

B) Monuments where only an "after" survey and only photographic documentation of the "before" are available:

- Matbackh al Alami

- Khan el Wazir gate

- Hammam an-Nasri

C) Monuments where only an "after" photographic documentation is available:

- al-Aadlieh mosque cristian-maronite cathedral

Medrasa e Moschea Al-Ridaieh

Old Governor building

al-Utrush mosque

Aslan Dada mosque

Al Bahrameah mosque

Al-Sultanieh, Ayyubidi, 1223 D.C. mosque

All image orientations were performed whereas I will leave the plotting to the students of the Aleppo school of architecture. In fact, I hope to come back to Aleppo and teach my photogrammetry in the local architecture school. This can be my small contribution to the reconstruction of the cultural heritage of Aleppo.

\subsection{The surveys allowing comparison}

A complete description of the monuments hereafter shown and their history can be found in "The Great Mosque of Aleppo | Muslim Heritage", in Hdjar (2007) and Gonella et al., (2005).

\subsection{Types of surveying}

There are three different types of surveys: 

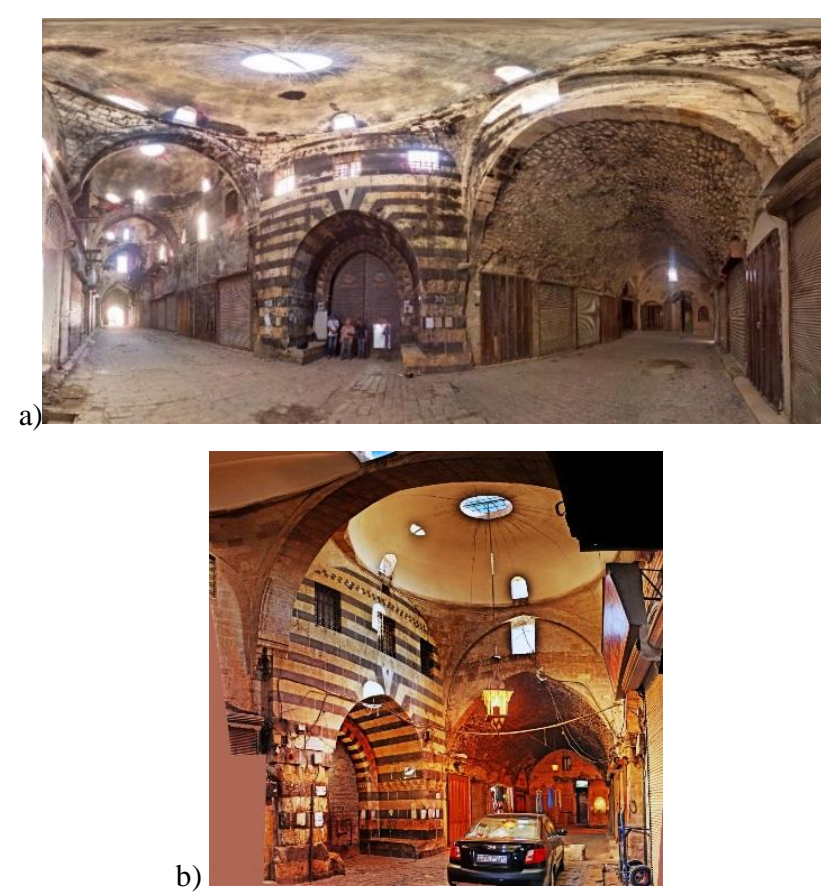

Figure 1: The old souq, current situation (a) and how it was in 2010 (b).

Al-Madina Souq (Arabic: سوق المدينة) is the covered souq-market located at the heart of the Syrian city of Aleppo within the walled ancient part of the city (Fig. 1). With its long and narrow alleys, al-Madina Souq is the largest covered historic market in the world, with an approximate length of 13 kilometers. ${ }^{[1]}$ It is a major trade centre for imported luxury goods, such as raw silk from Iran, spices and dyes from India and many other products. Al-Madina Souq is also home to local products such as wool, agricultural products and soap. Most of the souqs date back to the 14 th century and are named after various professions and crafts, hence the wool souq, the copper souq, and so on. Aside from trading, the souq accommodated the traders and their goods in khans (caravanserais) scattered within the souq. Other types of small market-places were called caeserias. Caeserias are smaller than khans in size and functioned as workshops for craftsmen. Most of the khans took their names after their function and location in the souq and are characterized by beautiful façades and entrances with fortified wooden doors. Al-Madina Souq is part of the Ancient City of Aleppo, a UNESCO World Heritage Site since 1986.

The so-called Matbakh (kitchen) of al-'Ajami of Aleppo (Fig. 2) is located about 150 meters west of the Citadel, on a modern street that connects the Citadel with the Great Mosque. In all likelihood, this was originally an Ayyubid palace that was built in the early 13 th century by the notable al-'Ajami family, making it the only remaining non-royal Ayyubid palace in Syria. Its identification rests on a passage in Ibn Shaddad that describes the Madrasa al-Sharafiyya, which was built by Banu al-'Ajami, and their nearby palace (https://archnet.org/sites/10559).

Khan al-Wazir (Fig. 3) is a caravan-serray located in the old city of Aleppo between the Citadel and the Great Mosque. The Ottoman governor of Aleppo, Qara Muhammad Paşa commissioned the building between 1678 and 1682/1083 AH. (https://archnet.org/sites/2865) a)

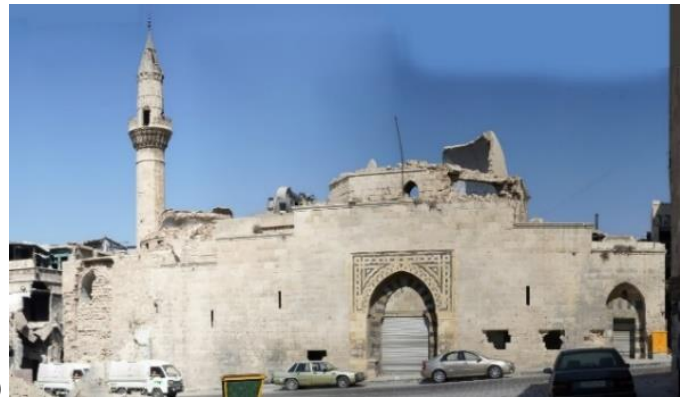

b)

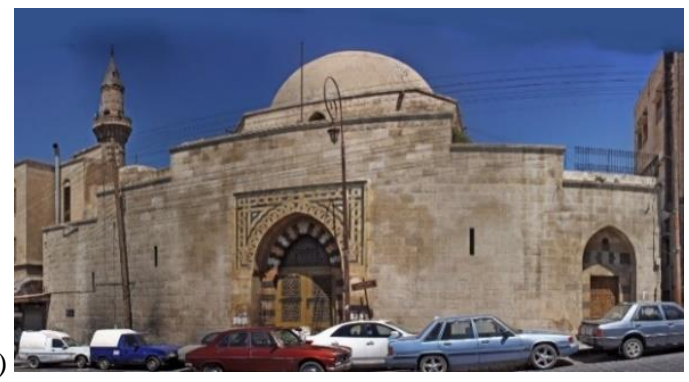

Figure 2: Matbackh al Ajami, current situation (a) and how it was in 2010 (b).
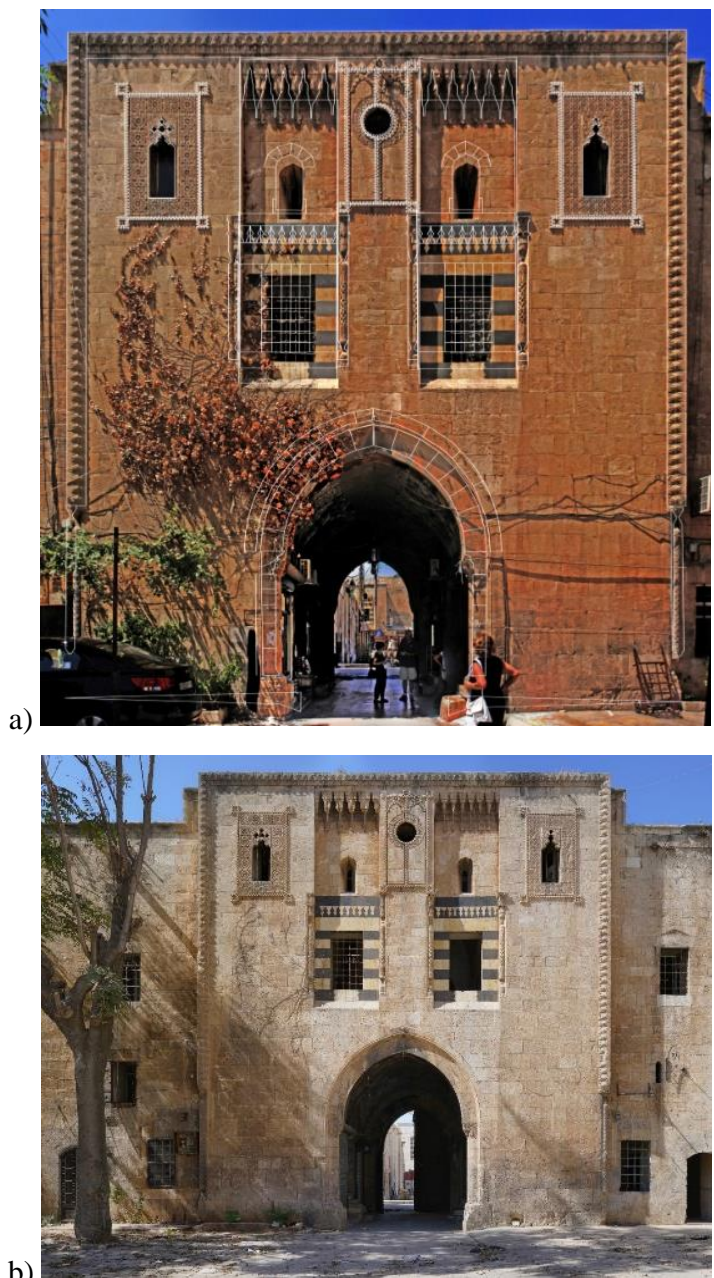

Figure 3: Khan el wazir, caravan-serray in the typical ablaq style, as it was (a) and as it is now (b). 


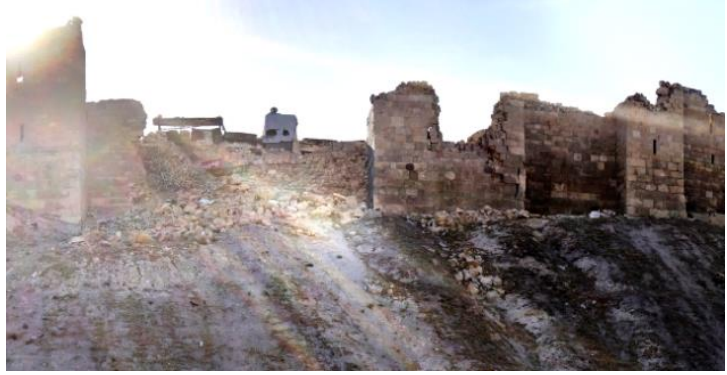

b)

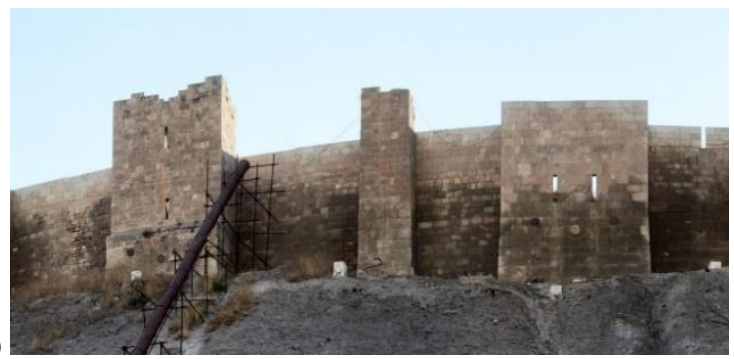

Figure 4: Citadel walls, current situation (a) and how it was in 2010 (b).

A lot has been written about the Citadel of Aleppo (Fig. 4), news can be found in Gonella et al. (2005). The citadel rises on a conical truncated hill with a height of 40 meters; it has an elliptical shape with the axes of $400 \times 200$ meters. The city walls extend for about $900 \mathrm{~m}$. To the south and to the north two defensive towers are outside the walls.

a)

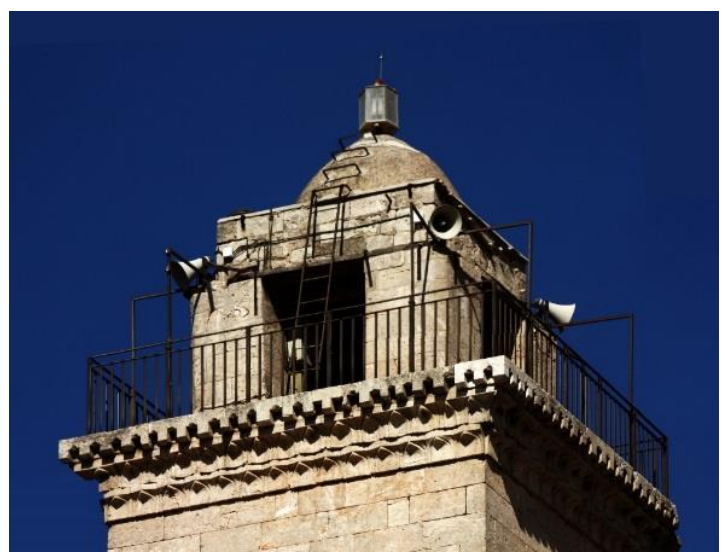

b)

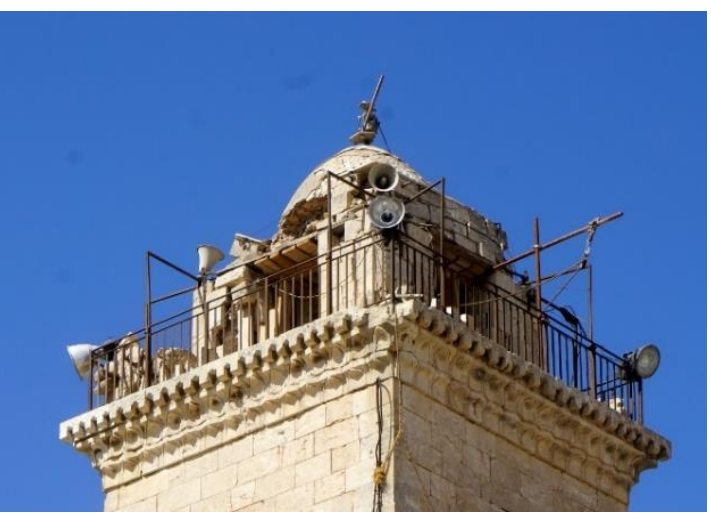

Figure 5: Minaret of the citadel mosque, current situation (a) and how it was in 2010 (b).

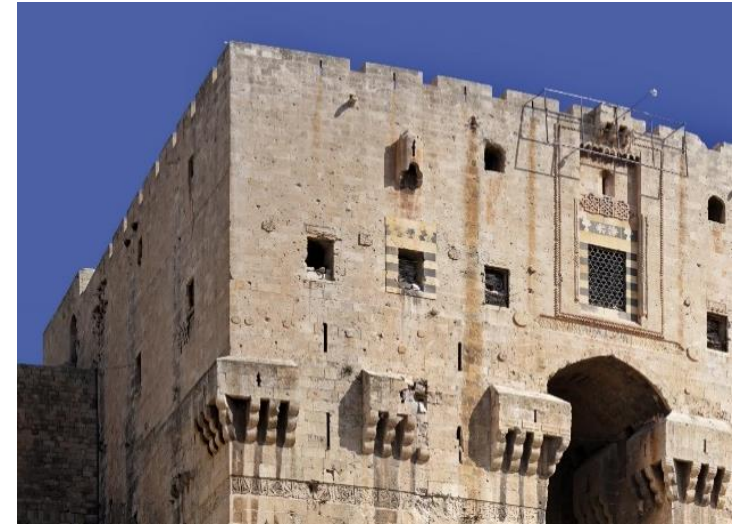

Figure 6: Entrance tower of the Citadel.
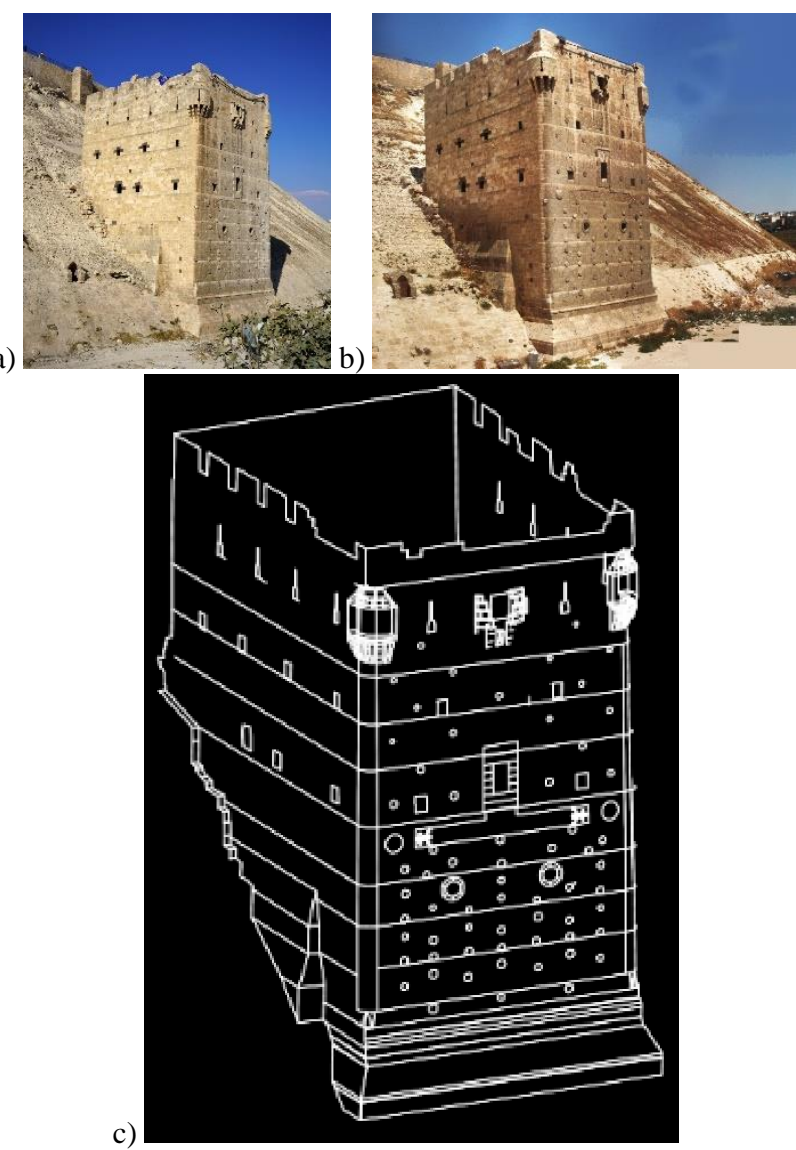

Figure 7: The Southern tower of the Citadel now (a), as it was (b) and a 3D restitution (c), by Oma e-Beik.

The Great Mosque (or the Umayyad Mosque) of Aleppo (Fig. 8) is the largest and one of the oldest mosque in the city of Aleppo. It is located in al-Jalloum district of the Ancient City of Aleppo, a World Heritage Site, near the entrance to Al-Madina Souq. It was built in the beginning of the 8th century CE. However, the current building dates back to the 11th through 14th centuries. The minaret was built in 1090, and was destroyed during fighting in the Syrian civil war in April 2013. 
a)
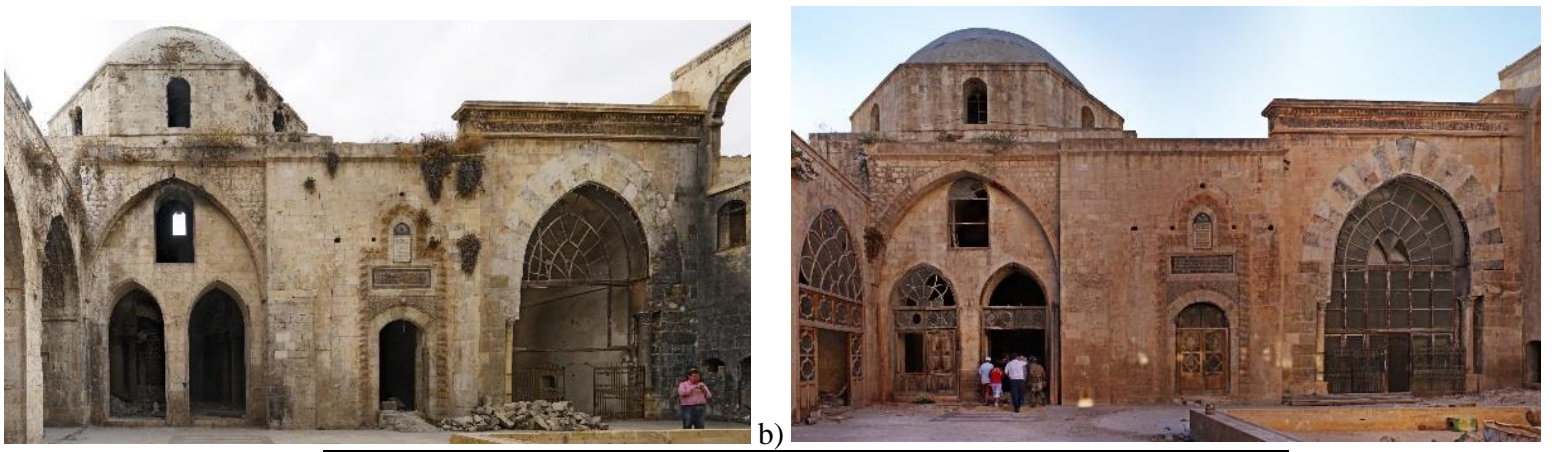

c)

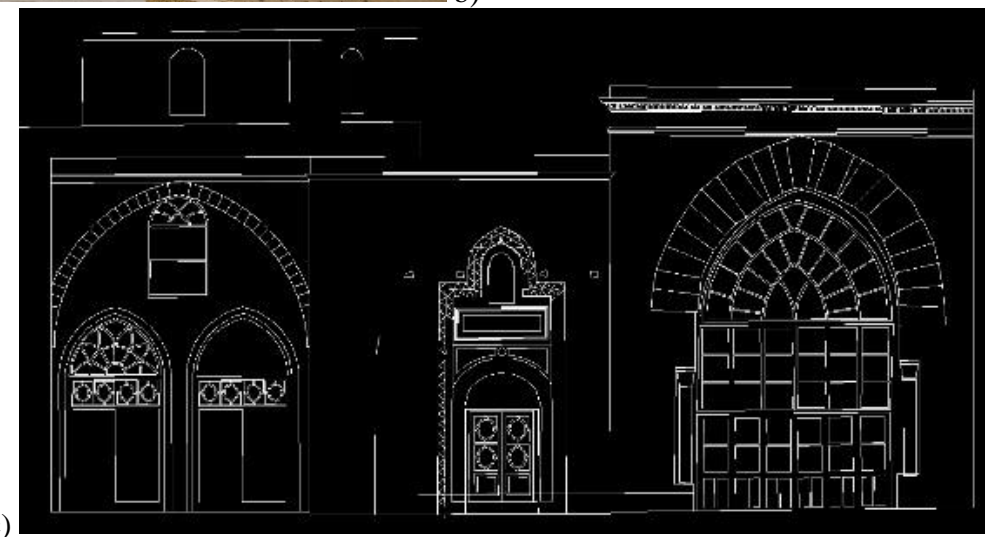

Figure 8: Al Haways medrasa, current situation (a), how it was in 2010 (b) and 3D restitution (c) by F.Di Stefano.

a)

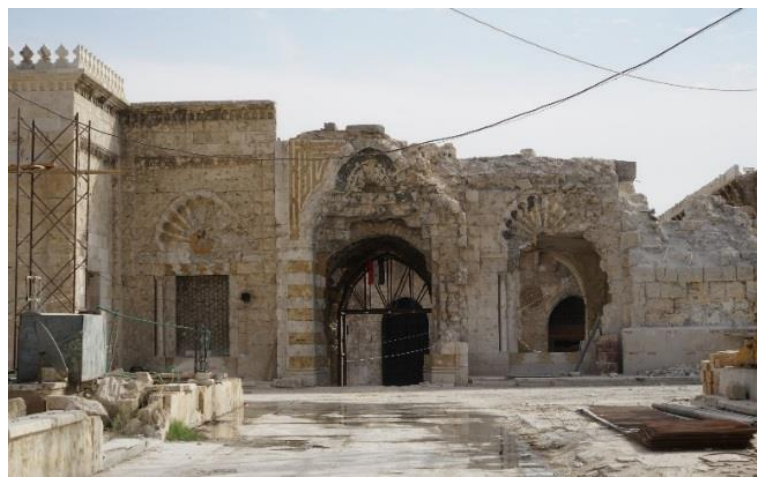

b)

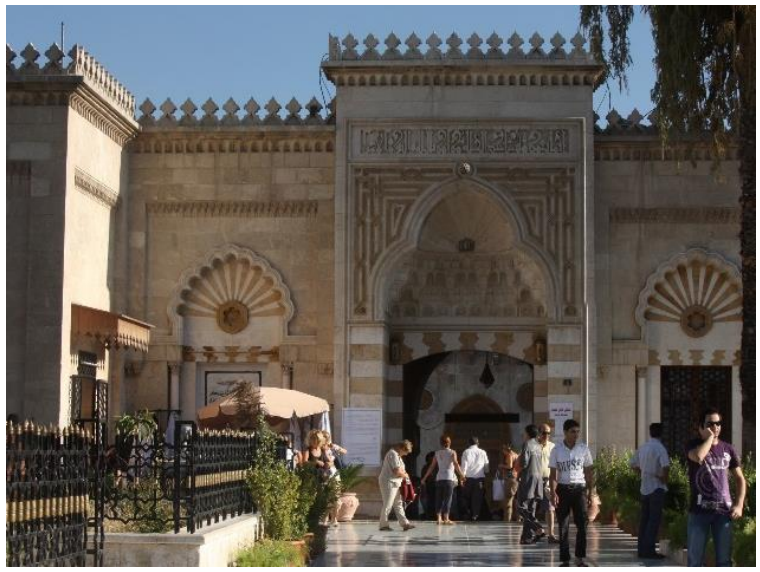

Figure 9: The entrance gate to the great Mosque, current situation (a) and how it was in 2010 (b).

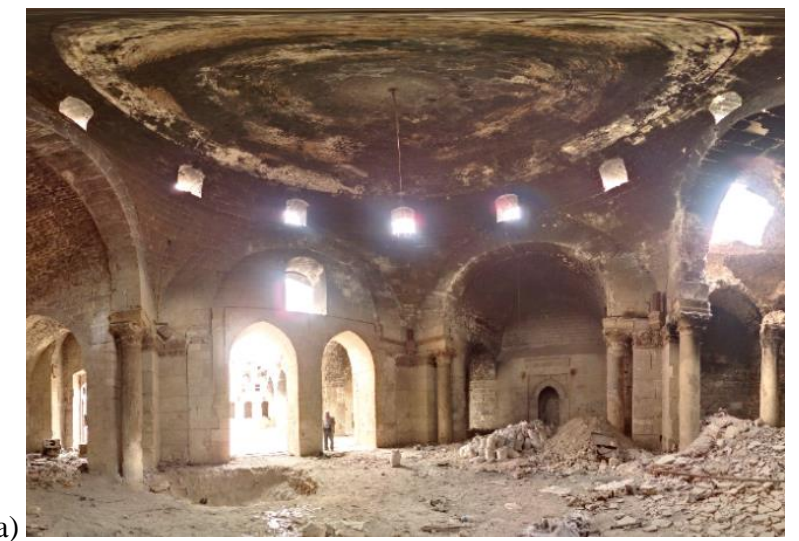

b)

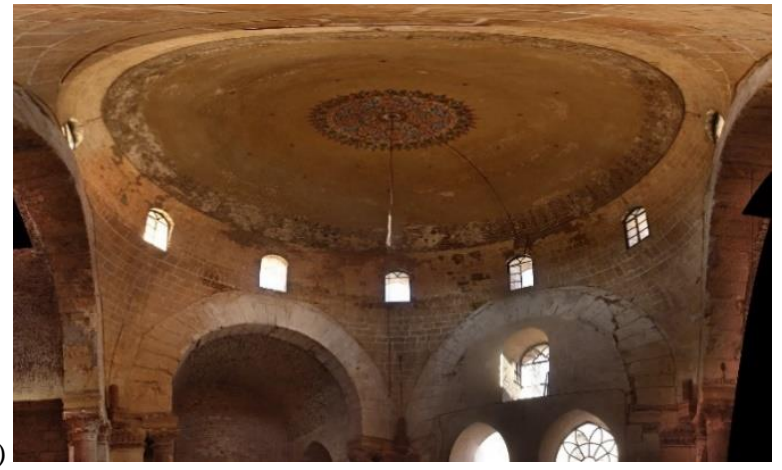

Figure 10: The el Haways madrasa interior, current situation (a) and how it was in 2010 (b). 
a)

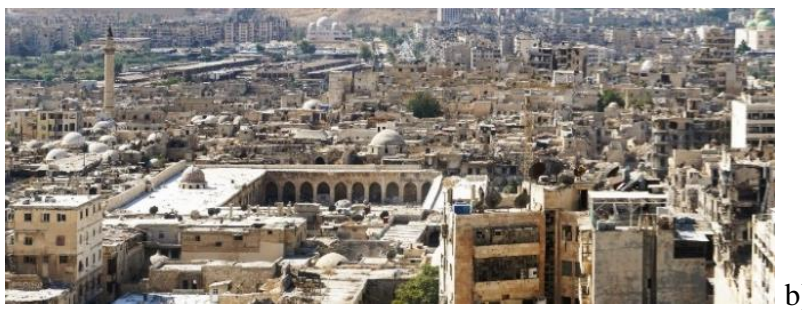

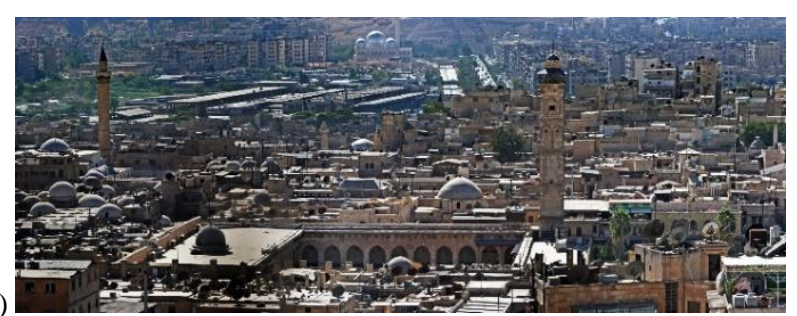

current situation (a) and how it was in 2010 (b).

\section{THE GREAT UMAYYADS MOSQUE AND THE MINARET}

The works for the restoration of the mosque and for the reconstruction of the minaret began in February 2018. The minaret, located in the northwest corner of the mosque, was erected under the first sultan Seljud in 1090. It was 45 meters of height. It had five levels that ended with an overhanging wooden balcony for the muezzin. The decoration consisted of relief ornaments. The minaret has been destroyed in 2013. (Source: SiriaLibano.)

The minaret had already been restored in 2007 , so accurate measurements are yet available. A committee, composed by civil, religious, professional and academic authorities, takes care of the restoration-reconstruction work. The first phase of the restoration consists in the recognition of the external blocks that will be relocated in the same position where they were. They are in total about 2500 blocks of dimensions $0.5 \times 0.55 \times 1.10 \mathrm{~m}$ approximately, and 1300 of them placed outside in the walls. In the court of the mosque the blocks are placed waiting for the recognition and classification. The workers lift each block with a crane and take photographs of it from all positions. With a specially written program in mathlab, the recognition is performed semi-automatically. The program provides 5-6 candidates and the operator makes the final choice. My highresolution photographs of the minaret will help the recognition and confirm the identifications already made. The identification is expected to reach $70 \%$ of the total. Many blocks are broken and no more suitable therefore they will be replaced. The work is expected to finish by 2020 .

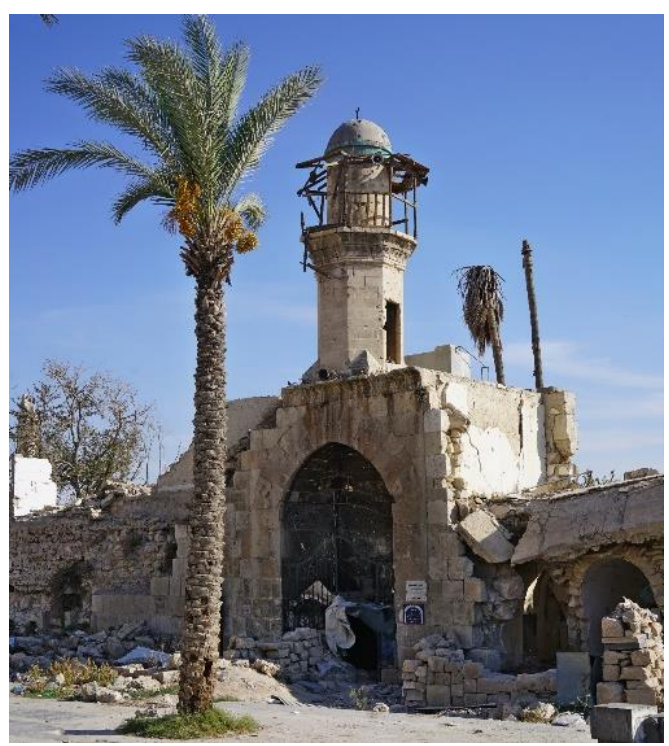

Figure 12: Al-Sultanieh, Mosque, Ayyubids, 1223 D.C. It was containing the tomb of Zaher al-Ghazi, sun of Saladin, the governor who restored the Citadel and built the walls.
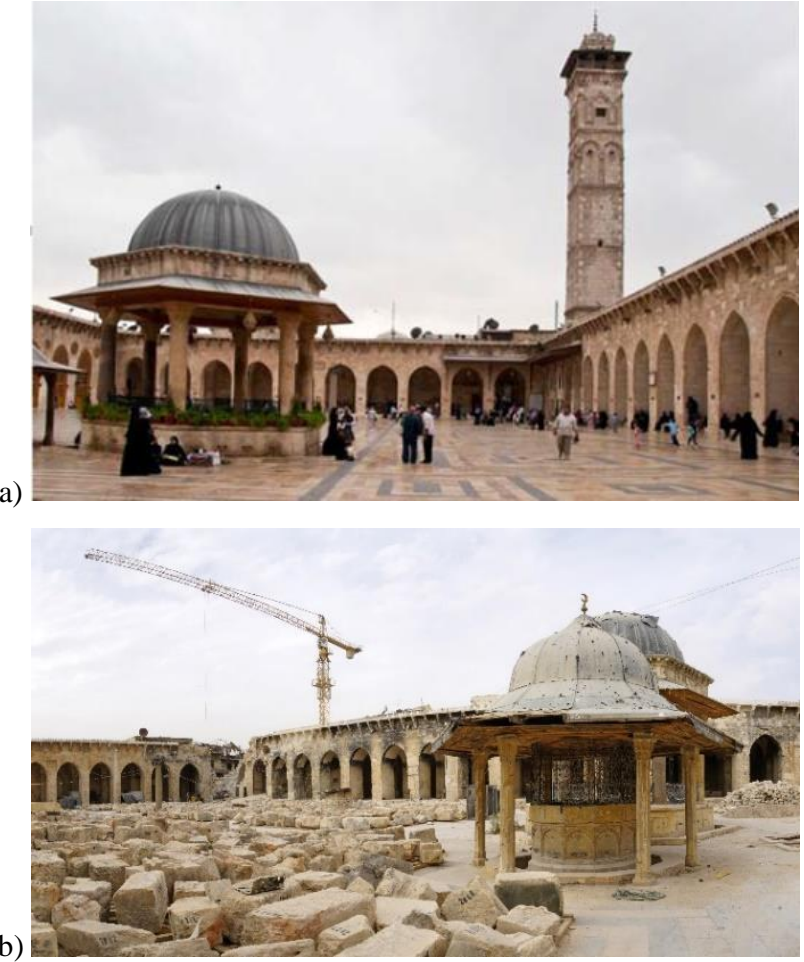

Figure 13: The Minaret of the Great Umayyad Mosque before the war and after the war.

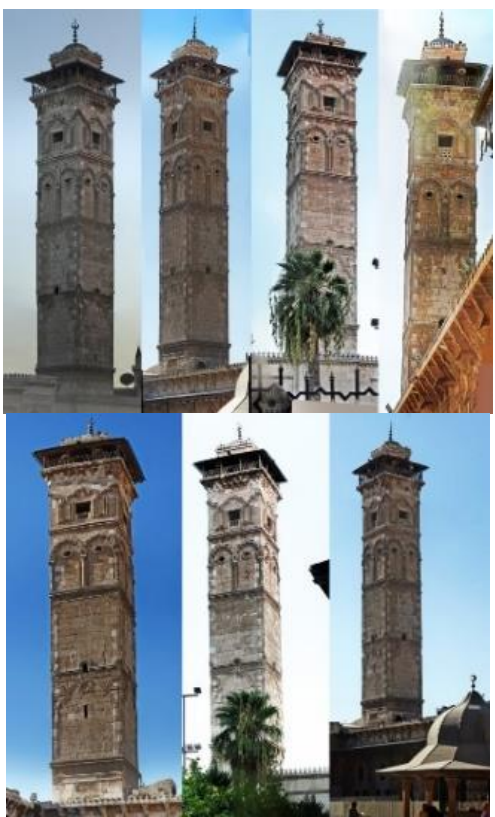

Figure 14: Some of the 22 spherical panoramas shot in 2010, used for the $3 \mathrm{D}$ reconstruction of the monuments. 


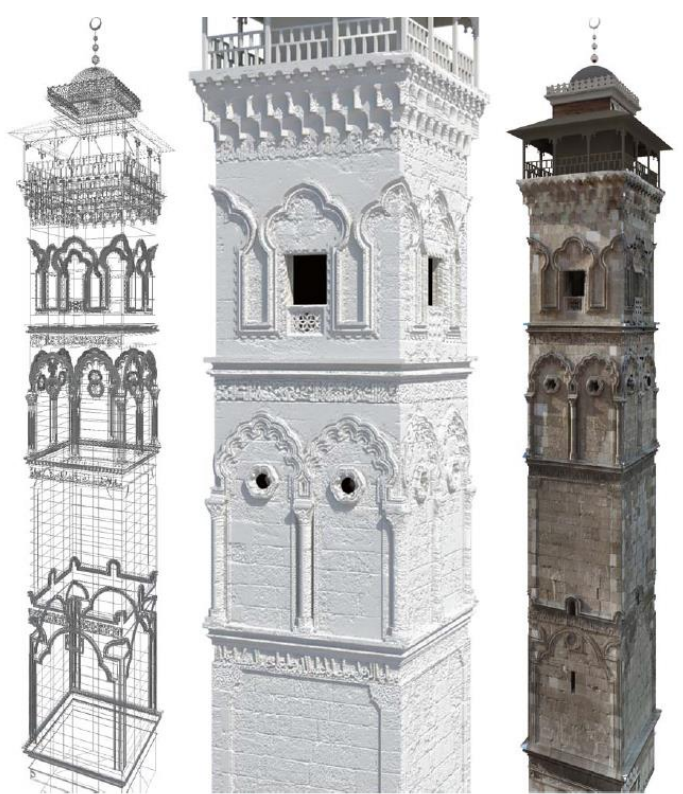

Figure 15: The 3D model of the minaret by Wissam Wabeh.

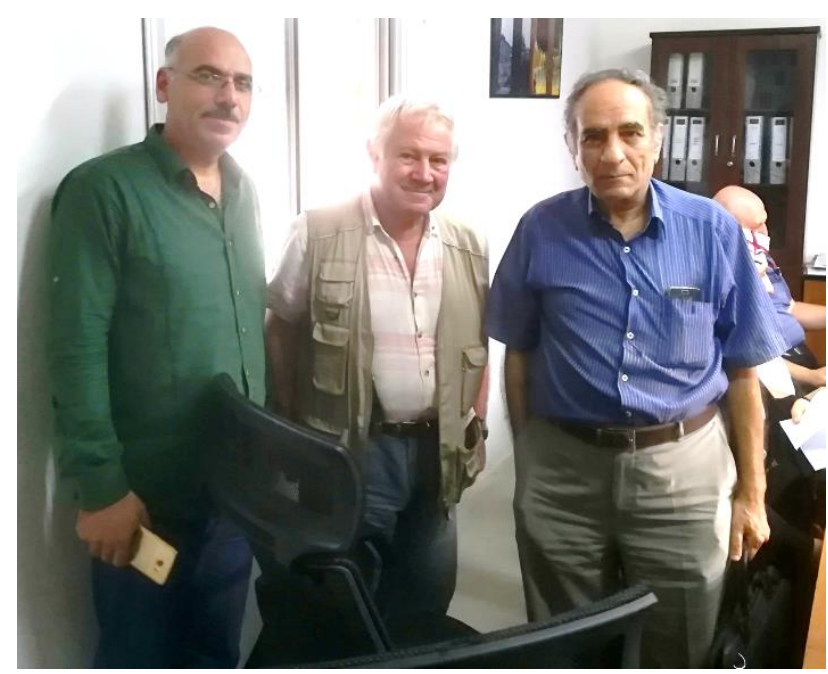

Figure 16: Myself with prof. Hassan Jabreeni, photogrammetrist (left) and prof. Ammar Kaadan, structural eng. (right).

\section{CONCLUSIONS}

The restitution of the surveyed monuments will happen later in a second time. These evaluations prove undoubtedly that photogrammetric coverage is an essential instrument for the protection of the monuments. Students of the Faculty of Architecture of the University of Aleppo will plot the monuments. In will be the occasion to assess the damages suffered. Now we can make already some observations. Aleppo is included in the UNESCO World Heritage List. The majority of the monuments in the city of suffered very huge damages when not permanently destroyed. Apart the thousands of dead people, the destruction is concentrated in the historical center against the historical buildings. The difference in color between before and after the war, is very much evident: the buildings are now whiter and the colors are duller, probably due to the limestone dust of the destroyed stones.

The process of recovery, restoration, reconstruction will be long and difficult, it will require many efforts and investments. The documentation of cultural heritage can have a small but significant part in this process.

\section{ACKNOWLEDGEMENTS}

My deep gratitude goes to Dr. Reme Sakr, of the Living Heritage programme, of the Syrian Trust for Developments, to her colleague Jean, to my precious guides Rasha and Jihad for bringing me around Syria and allow me to visit and survey so many important and beautiful places.

\section{REFERENCES}

Di Stefano F., 2016. Il patrimonio perduto della Siria, documentazione e archiviazione - Graduation Thesis, Università Politecnica delle Marche, Ancona

Fangi, G., 2007. The Multi-image Spherical Panoramas as a Tool for Architectural Survey. ISPRS International Archives of Photogramm. Remote Sens. Spatial Inf. Sci, Vol. XXXVI, Part. 5/C53, CIPA Archives, Vol. XXI, pp. 311-316.

Fangi, G., 2015. Documentation of some Cultural Heritage Emergencies in Syria In August 2010 by Spherical Photogrammetry. ISPRS Ann. Photogramm. Remote Sens. Spatial Inf. Sci., Vol. II-5/W3, pp. 401-408.

Fangi, G., Nardinocchi, C., 2013. Photogrammetric Processing of Spherical Panoramas. The Photogrammetric Record, Vol. 28(143), pp. 293-311

Fangi, G, Wahbeh, W., 2013. The Destroyed Minaret of the Umayyad Mosque of Aleppo - The Survey of the Original State. European Scientific Journal, Vol. 4, pp. 7857-7881

Fangi, G., Wabeh, W., Malinverni, E., Pierdicca, R., 2016. Realized and Stored 3D Models in a Dedicated Database to Document Some Cultural Heritage Emergencies in Syria. Proc. $10^{\text {th }}$ International Congress on The Archaeology of The Ancient Near East, Vienna, Austria, 25-29 April, 2016

Gonella, J., Khayyata, W., Kohlmeyer, K., 2005. Die Zitadelle von Aleppo und der Tempel des Wettergottes, Rhema-Verlag, Münster, ISBN 978-3-930454-44-0.

Hdjar, A., 2007. Die Denkmaeler von Aleppo. Automobil and Touring Club of Syria, Aleppo.

Silver, M., Fangi, G., Denker, A., 2018. Reviving Palmyra in multiple dimensions - Images, Ruins and Cultural Memory. Whittles Publishing, ISBN 978-1-84995-296-5.

Wahbeh, W., Nebiker, S., Fangi, G., 2016. Combining Public Domain and Professional Panoramic Imagery for The Accurate and Dense 3d Reconstruction of the Destroyed Bel Temple in Palmyra. ISPRS Ann. Photogramm. Remote Sens. Spatial Inf. Sci., Vol. III-5, pp. 81-88.

The Great Mosque of Aleppo | Muslim Heritage: http://www.muslimheritage.com

https://www.calameo.com/books/0033299721336e74edda2

http://www.sirialibano.com/siria-2/siria-distrutto

https://youtu.be/axdhppiekG4 